\section{The Use of Bahasa Indonesia in the ELT Classroom}

\author{
Baharuddin Pasaribu \\ CRIAS Language Center, Bogor
}

Abstract: This paper presents a survey of te use of Bahasa Indonesia in ELT classroom. The respondents of this survey were 265 students from various private universities in Bogor. It was assumped that all respondents who answered the questionnaires understood the aims of the survey. The results show, among others, that many of the students stated that Bahasa Indonesia should be used in ELT classroom and almost half the number of the students liked their teacher's use of Bahasa Indonesia. Some required conditions to use Bahasa Indonesia include the difficulty of the concepts to be explained, the degree of comprehension of the students, and class administration.

Keywords: bahasa Indonesia, ELT classroom

When I was doing my survey, my main concern was basically came from my own experience when I was teaching a class of adults who insisted me to use Bahasa Indonesia most of the time. In particular when explaining new or strange words. At the end of the course, in round up session, I realized that their reply of 'yes' to the question: Do you understand? was only a false reply to avoid a feeling of being stupid. They said: "How can we understand if you speak English continuously?

Then it became my inspiration to conduct a survey to see the extent to which the use of Bahasa Indonesia is applicable in ELT classroom. I was trying to move from my old view that students should be forced to a situation where target language-English (L2)-is overwhelmingly a dominant language of instruction over the use of Bahasa Indonesia (L1). L1 should, to some extent, be limited if not avoided since the exposure to L2 is expected to give a conducive situation in ELT classroom. I am looking at a room where $\mathrm{L} 1$ should coexist and cooperate well with $\mathrm{L} 2$, and for that reason I try to involve my students to take part in a survey and hopefully arrive at some interesting points.

\section{METHOD}

Two hundred and sixty five (265) students from various private Universities in Bogor, participated in filling and returning my questionnaire. All respondents are my students and were selected randomly involving senior and junior students, and combining students whose major are English and non-English Department. The profile of private colleges is as follow:

1. STIE TRIGUNA Bogor (First Semester Students)

2. STIE BINANIAGA Bogor (First and Second Semester Students)

3. AMIK BINANIAGA Bogor (Third and Fifth Semester Students)

4. ST-MIPA Bogor (First Semester Students)

5. Students of FKIP Jurusan PBI UIKA Bogor (Second, Fourth, and Sixth Semester Students).

6. Participants of TOEFL Preparation Class ARMP/PATTP Department of Agriculture who were attending an English training at CLC Bogor.

\section{BASICASSUMPTION}

In this survey I assumed that all respondents understood the aims of this survey, and therefore answered the questionnaires correctly and honestly. Prior to the paper distribution I explained the aim of the survey and how to fill the paper correctly.

I observed almost all the filling process on the spot, only a few students took the questionnaire home and return them later. I estimated that about $90 \%$ of the distributed questionnaires were returned. Raw data was then arranged by using table and tally systems and repeated 3-4 times to get accuracy.

\section{WEAKNESSES}

This survey was carried out to uncover my basic assumption that Bahasa Indonesia has an important role in English teaching and learning processes. Considering that the survey was done on a small-scale basis, it is certain that the results of this survey did/will not represent the real condition of the issue above. It is like an iceberg phenomenon, what was 
seen is just a little part of the real problem. Therefore, it is hoped that this survey will initiate further and more thorough survey covering national wide.

Within the limitation of time, respondents and types of questions, this paper will focus on eight questions as can be seen in the attached questionnaire. Other factors, such as, the availability of teaching facilities and equipment, the rate of exposure to the target language, students' interest and the work opportunity in the field of English, teaching-learning method are not discussed here. The data simply shows the students" perception and general trend of students who are studying at Private Universities in Bogor regarding the use of Bahasa Indonesia in ELT Classroom.

\section{THE RESULTS OF THE SURVEY}

Two hundred and sixty five (265) respondents participated and filled the questionnaire in this survey. The following is the modified result:

1. In your opinion, should Bahasa Indonesia be used in ELT Classroom? $(\mathrm{N}=265)$

Yes $=187(70,57 \%) \quad$ No $=78(29,43 \%)$

2. What do you think of a teacher/lecturer who speaks Bahasa Indonesia in his/her teaching process? $(\mathrm{N}=265)$

a. I like it most of the time $125(47.16 \%)$

b. I quite like it $65(24.53 \%)$

c. I like it very much $64(24.16 \%)$

d. I do not like it at all $11(04.15 \%)$

3. In your opinion, in which of the following situations Bahasa Indonesia should be used? ( $N=700)$

a. Explaining a difficult concept $237(33.86 \%)$

b. Translating difficult/strange words $117(16.71 \%)$

c. Explaining new vocabulary $75(10.71 \%)$

d. Checking student's understanding $59(08.43 \%)$

e. Explaining the meaning of a dialogue in a cassette $46(06.57 \%)$

f. Introducing new material/new lesson $42(06.00 \%)$

g. Explaining the relationship of English and Bahasa Indonesia 37 $(05.28 \%)$

h. Putting the learners at ease $23(03.29 \%)$ i. Explaining and clarifying test/exercise $18(02.57 \%)$

j. Summarizing finished materials $17(02.43 \%)$

k. Giving instructions \& orders $6(00.86 \%)$

1. Carrying out test or examination $6(00.86 \%)$

m. Making jokes with the participant $6(00.86 \%)$

n. Forming study group in class activity $4(00.57 \%)$

o. Others (please specify) Explaining idiom and formula, Communication tool $7(01.00 \%)$ Helping students to understand more

4. In your opinion, what is the rough percentage use of Bahasa Indonesia in ELT classroom? $(\mathrm{N}=265)$
a. $21 \%-30 \%=62(23.40 \%)$
b. $51 \%-60 \%=60(22.64 \%)$
c. $31 \%-40 \%=61(23.00 \%)$
d. $41 \%-50 \%=39(14.72 \%)$
e. $11 \%-20 \%=34(12.83 \%)$
f. $61 \%-70 \%=3(1.13 \%)$
g. $00 \%-10 \%=2(0.76 \%)$
h. $71 \%-80 \%=2(0.76 \%)$
i. $81 \%-90 \%=2(0.76 \%)$
j. $91 \%-100 \%=0(0.00 \%)$

5. In accordance with question No. 4 , how often do you think Bahasa Indonesia should be used in ELT Classroom? $(\mathrm{N}=265)$
a. Sometimes $205(77.36 \%)$
b. Hardly ever $30(11.32 \%)$
d. More often $20(07.55 \%)$
e. Always $8(03.02 \%)$
f. Never $2(0.75 \%)$

6. If you choose YES for question No. 1, why do you prefer the use of Bahasa Indonesia in ELT Classroom? $(\mathrm{N}=345)$

a. To make understanding easier $218(63.19 \%)$

b. To give a feeling of quietness and avoid nervous $47(13.62 \%)$

c. To give comfort and raise self confidence $31(08.98 \%)$

d. Others (please specify) Motivating students Increase understanding Introducing new words $26(07.54 \%)$ Bahasa Indonesia as a mother tongue Low level of English

e. To give a feeling of free from stress $23(06.67 \%)$ 
7. What is the role of Bahasa Indonesia for you in learning English? $(\mathrm{N}=269)$

a. Quite helpful $161(59.85 \%)$

b. Very helpful $67(24.91 \%)$

c. A little helpful $35(13.01 \%)$

d. Others (please specify) Bahasa Indonesia minded, Low level class $4(01.49 \%)$ Help understanding

e. Unhelpful $2(00.74 \%)$

8. What is your perception of a lecturer/teacher who teaches English through English? $(\mathbb{N}=265)$

a. Good $123(46.42 \%)$

b. Very good $58(21.89 \%)$

c. Nothing special $50(18.87 \%)$

d. Not good $31(11.69 \%)$

e. Over acting $3(01.13 \%)$

\section{CONCLUSION}

In summary, the majority of students in this survey $(70.57 \%)$ agree that Bahasa Indonesia should be used in ELT Classroom. The level where should Bahasa Indonesia be used is not covered in this study. The underlying reason being were:

a. To make understanding easier

$218(63.19 \%)$

b. To give a feeling of quietness and avoid nervous $47(13.62 \%)$

c. To give comfort and raise self confidence $31(08.98 \%)$

d. Others (please specify)

Motivating students

Increase understanding

Introducing new words

$26(07.54 \%)$

Bahasa Indonesia as a mother tongue

Low level of English

e. To give a feeling of free from stress

$23(06.67 \%)$

This probably is not a surprise for those who used to speak in Bahasa Indonesia in their ELT classes. However, for others notably those who were trained in the so-called 'communicative approach', will find this result is a bit shakey. As we probably all know that in this particular approach there is a strong tendency to reduce, avoid or even abolishing the use of students' mother tongue.
When students were asked in which class activities should Bahasa Indonesia be used, respondents came up with various answers. The answers fall into three broad categories:

a. Explanation, Students need Bahasa Indonesia in explaining a difficult concept $(33.86 \%)$, in translating strange or new words in a passage $(16.71 \%)$ and in explaining new words $(10.71 \%)$.

b. Checking comprehension (both in written and spoken materials). Students agreed that Bahasa Indonesia to check that: they have understood the materials $(8.43 \%)$, or the spoken dialogues in a cassette $(6.57 \%)$, introducing new material or chapter or unit of a course book (6,00\%), and but not least checking students' perception concerning the relationship between Bahasa Indonesia and English $(5.28 \%)$.

c. Class administration. Students feel that in the following activities the use of Bahasa Indonesia plays a minor role. Helping them at ease (3.29\%), clarifying test or examination $(2.57 \%)$, conducting the test $(6.00 \%)$ and making jokes $(6.00 \%)$. What is left then is grouping students in a class activity $(0.57 \%)$.

Almost half of the respondents $(46.42 \%)$ think that it is good if a lecturer/teacher use English in the class. This shows that they like being exposed to the target language, and according to them, the right percentage of Bahasa Indonesia in ELT falls somewhere between: $21 \%-30 \%$ $(23.40 \%) ; 51 \%-60 \%(22.64 \%)$, and $31 \%-40 \%(23.00 \%)$. However, respondents seem to confuse when the percentage is converted into words. When asked: how often do you think Bahasa Indonesia should be used in ELT Classroom, they came up with "Sometimes" (77.36\%).

As mentioned right in the beginning that this survey should shed light into further and more thoroughly study, it is then a matter of whether or not we are willing to take this opportunity.

\section{REFERENCES}

Atkinson, D. 1987. The mother tongue in the classroom: a neglected resource? ELT Journal Vol. $41 / 4$.

Doff, A. 1988. Teach English Trainer's Handbook. Cambridge: Cambridge University Press.

Dyer, B. 1996. L1 and L2 composition theories: Hillocks 'Environmental mode and task-based language teaching in ELT Journal Vol. 50/40. 
148 TEFLIN Journal, Volume XII Number 1, February 2001

Eldridge, J. 1996. Code Switching in a Turkish secondary school in ELT Journal Vol. 50/4.

Hardbord, J. 1992. The use of mother tongue in the classroom in ELT Journal Vol. 46/4.

Medgyes, P. 1992. Native or non-native: who's worth more? in ELT Journal Vol. $46 / 4$.

Nicklin, M. 1991. Should Indonesian be used in the ELT Classroom? Local Workshop at UI 12/7/1991.

Willis, J. 1990. Teaching English through English Longman UK Group Limited. 